\title{
EARLY CRETACEOUS PALYNOMORPHS FROM THE ZUATA AREA, EASTERN VENEZUELA
}

\author{
EFE SINANOGLU
}

\section{RESUMO $^{2}$}

Este trabalho é baseado em estudos palinológicos e petrográficos do testemunho de um poço (MARAVEN, S. A.), situado na área de Zuata, Venezuela. Os palinomorfos recuperados são atribuí. dos a 19 gêneros e 33 espécies de esporos e 9 gêneros e 26 espécies de pólen. A idade indicada é, mais provavelmente, ?Aptiano-Albiano médio inferior. São feitas comparaçōes com modelos já estabelecidos de provincias microflorísticas do Cretáceo Inferior (BRENNER, 1976; HERNGREEN, $1976,1981)$ e as implicaçóes discutidas. Estudos palinológicos e sedimentológicos sugerem um ambiente de deposição fluvial, sob condiçøes áridas, numa região topograficamente pouco movimentada.

\section{ABSTRACT}

This report is based on palynological and petrographical studies of a core from a Zuata area well (MARAVEN, S. A.). Palynomorphs encountered have been assigned to 19 genera and 33 species of spores and 9 genera and 26 species of pollen grains. The most probable age is ?Aptian-Early Middle Albian. A comparison with previously published Early Cretaceous microfloral province concepts (BRENNER, 1976; HERNGREEN, 1976, 1981) has been made and implications are discussed. Paly. nological and sedimentological studies suggest a fluvial environment in arid conditions on a flat topography.

\section{INTRODUCTION}

This report is based on palynological and petrographical studies of a core sample from a Zuata area well (MARAVEN, S.A.), drilled in the petroleum belt of the Orinoco River, Faja Petrolifera del Orinoco (Fig. 1). The core (Fig. 2) represents an interval of $20^{\prime}(6.096 \mathrm{~m})$ from $4175^{\prime}(1272.5 \mathrm{~m})$ to $4195^{\prime}(1278.6 \mathrm{~m})$ within the basal section of the Cretaceous Temblador Formation, which closely overlies the top of the Paleozoic basement (16' below).

The Early Cretaceous palynomorphs recovered from the sample at $4176^{\prime} 9$ "' $(1273.11 \mathrm{~m})$ belong to 19 genera and 33 species of spores and 9 genera and 26 species of pollen. Marine palynomorphs are absent.

This study, to the author's knowledge, is the first description of an Early Cretaceous microflora from Venezuela. Other studies of Cre. taceous palynology in South America may be found in BOER et al. (1965), MULLER (1966), BRENNER (1968), REGALI, UESUGUI \&
SANTOS (1974), LIMA (1974) and HERNGREEN $(1972,1973,1974,1975,1976,1981)$

Here an attempt has been made to place the recorded assemblage into Brenner's (1976) Barremian-Cenomanian floral provinces as well Herngreen's (1976, 1981) Cretaceous microfloral provinces and to discuss the implications. It is hoped that the results obtained will provide valuable assistance to other researchers of South America and Africa and also give some insight into the early migration of angiosperms.

\section{PETROGRAPHICAL DESCRIPTION OF THE CORE}

Petrographical and Scanning Electron Microscopy (SEM) studies have shown that the lithology consists mainly of white, well-consolidated, detrital, kaolinite-rich (20-80\%), moderately sorted medium- to coarse-grained sandstone with subangular to subrounded, fractured

- INTEVEP, S. A., Ciencias de la Tierra, Caracas, Venezuela.

2 Resumo em português foi feito pelo Coordenador Editorial T.R.F. 


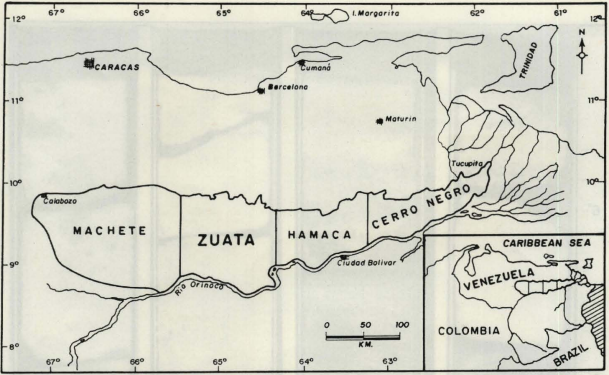

Fig. 1 - Location map.

quartz grains. The sedimentary structures consist of crudely stratified beds, interbedded with small scale cross-bedding $(20-80 \mathrm{~mm})$ which are often separated by subhorizontal erosional surfaces stained by reddish iron oxide minerals. Palynomorphs have been recovered from a kaolinite-rich, light-grey, well-sorted, fine to very fine sandy (subangular to subrounded quartz grains) kaolinitic-illitic claystone, rich in carbonaceous matter $\left(4176^{\prime}-4177^{\prime}\right)$

\section{SAMPLE PREPARATION AND METHOD OF STUDY}

Standard palynological and maceration procedure was used in preparation of the sample; namely, treatment with $\mathrm{HCL}, \mathrm{HF}$, centrifuging and the use of zinc bromide (specific gravity 2.2) as a heavy liquid; followed by oxidation by $\mathrm{HNO}_{3}$ for a short period with brief clearance in alkali using ammonium hy. droxide. Permanent scatter mounts were made as described by JEFFORDS \& JONES (1959), but using Entellan 7960 in place of thermoset plastic mounts.

The slides were examined at $400 \mathrm{X}$ magnification using a Zeiss photomicroscope equipped with a standard mechanical stage. Photo- graphs were taken using Agfa Isopan 21 film. Representatives of all spore and pollen taxa encountered are illustrated in Pls. I - XVII. All slides are on file in the Biostratigraphy section of the Earth Sciences Department, INTEVEP, S.A.

\section{COMPOSITION OF THE MICROFLORA}

The palynologically productive sample at 4176 '9" (1273.11 $\mathrm{m}$ ) has yielded 59 species of uncorroded and well-preserved spores and pollen

The assemblage, in general, is dominated by gymnosperm pollen and pteridophyte spores. Angiosperm pollen is extremely rare and its occurrence does not exceed $2 \%$ to $4 \%$ of the total assemblage. Bisaccates, tricolporates, triporites and polyporates have not been encountered. Broadly, it can be concluded that the gymnosperm pollen forms a major element in the microflora. Ephedra-type pollen and several species of Classopollis, including the types smaller and bigger than $30 \mu \mathrm{m}$ are frequently represented by high values with $25 \%$ and $20 \%$, respectively. Although the variety of pteridophyte spores is poor, they seem to comprise the other major component of the 


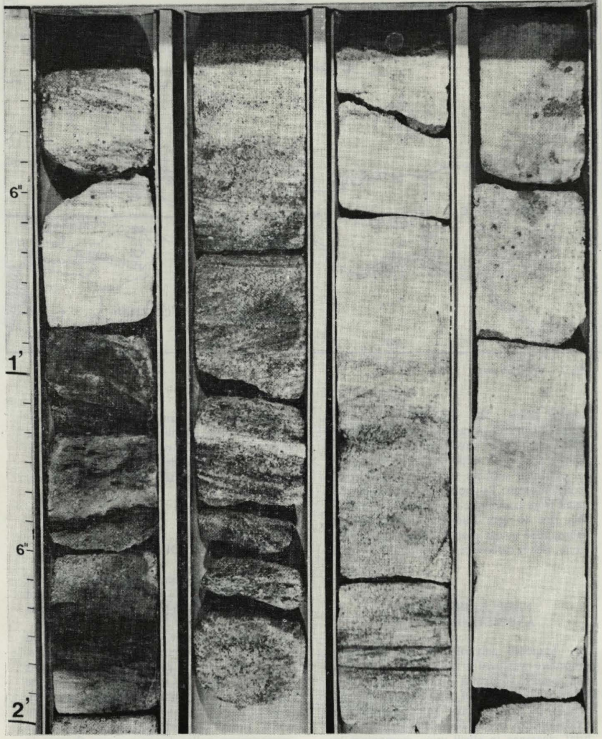

Fig. 2 - Part of the core $\left(4,175^{\prime}\right.$ to $4,195^{\prime}$ in terval) through the basal section of the Temblador Formation, Zuata area, Faja Petrolifera del Orinoco, Venezuela. Palynomorphs were recovered from the dark, carbonaceous portion in the lower left corner of the figure $\left(4,176^{\prime}\right.$ to $4,177^{\prime}$ interval $)$. 
assemblage. This can be illustrated by the occurrence of Cicatricosisporites spp. in relatively high values $(15 \%)$. Other quantitatively important constituents among the pteridophytes are species of Cyathidites ( $8 \%$ to $10 \%$ ) and Concavisporites (5\% to $7 \%$ ). Apart from the above-mentioned genera all others encountered do not seem to have any quantitative significance. The following species occur in percentages lower than $5 \%$, some of these species being recorded only as single specimens. Gleichenïdites apilobatus Brenner 1963 (Plate II, Fig. 2), Verrucosisporites sp. A (Plate II, Fig. 3), Verrucosisporites sp. B (Plate II, Fig. 4), Biretisporites cf. B. potoniaei Delcourt and Sprumont 1955 (Plate II, Fig. 6), Dictyophyllidites equiexinus (Couper) Dettmann 1963 (Plate II, Fig. 7), Contignisporites formicatus Dettmann 1963 (Plate VII, Fig. 3), Leptolepitides verrucatus Couper 1958 (Plate VIII, Fig. 1), Leptolepitides major Couper 1953 (Plate IX, Fig. 2), Foveotriletes sp. A (Plate VIII, Fig. 2), Klukisporites variegatus Couper 1958 (Plate VIII, Fig. 3), Lycopodiumsporites paleocenicus Dutta and Sah 1970 (Plate VHI, Fig. 4), Cingulatisporites verrucatus Regali, Uesugui and Santos 1974 (Plate IX, Fig. 3), Sergipea naviformis Regali, Uesugui and Santos 1974 (Plate IX, Fig. 5), Coptospora sp. A (Plate IX, Fig. 6), Coptospora sp. B (Plate IX, Fig. 7), Schizea reticulata Cookson 1956 (Plate XI, Fig. 1), Schizea certa Bolkhovitina 1956 (Plate XI, Fig. 2), Hamulatisporis hamulatis Krutzsch 1959 (Plate IX, Fig. 1), Velosporites sp. A (Plate X, Fig. 1), Callialasporites dampieri (Balme) Deu 1961 (Plate X, Fig. 2 and 4), Perotriletes pannuceus Brenner 1973 (Plate X, Fig. 3), Gnetaceaepollenites sp. A, (Plate XII, Fig. 1), Gnetaceaepollenites sp. B, (Plate XII, Fig. 2 and 4), Gnetaceaepollenites sp. C, (Plate XII, Fig. 3), Gnetaceaepollenites sp. D (Plate XII, Fig. 5), Gnetaceaepollenites sp. E (Plate XII, Fig. 6), Zonalapollenites sp. A (Plate XV, Fig. 4), Retitricolpites vulgaris Pierce 1961 (Plate XV, Fig. 5), Eucommidites sp. A (Plate XV, Fig. 6), Retimonocolpites sp. A (Plate XVIII, Fig. 4) and Monosulcites sp. A (Plate XVIII, Fig. 5).

\section{DISCUSSION AND CONCLUSIONS}

The concept of Barremian-Cenomanian floral provinces was introduced by BRENNER in 1976. The provinces he proposed from south to north (Fig. 3) and their possible climatic patterns are as follows:
The Northern Laurasian Province (NLP): $60^{\circ} \mathrm{N}$.

Temperate humid climate; now above

The Southern Laurasian Province (SLP):

Warm temperate to subtropical humid; now in the middle latitudes of the Northern Hemisphere.

The Northern Gondwana Province (NGP):

Tropical semiarid; presently from the northern coast of South America and Africa to some undetermined latitude south of the equator.

The Southern Gondwana Province (SGP):

Warm temperate to subtropical humid; now in southern regions of South America and Africa, and including Australia, New Zealand and India.

According to Brenner's concept, Venezuela should be placed in NGP, and indeed the microflora does show some resemblance to Aptian-Albian assemblages from other localities in similar latitudes also placed within NGP. However some dissimilarities exist. Most notably this assemblage contains no bisaccate pollen, which is normally considered one of the most important characteristics of this province. Equally, while the low diversity of pteridophyte spores is characteristic, the Venezuelan material is somewhat unusual in the higher frequency of Schizeaceous types, whereas these have previously been thought to be rare (BRENNER, 1976). The absence of numerous and diverse cycadophytes is also anomalous. In northeastem Peru, Brazil, West Africa and Israel the polyplicate grains of the Ephedraceae are very numerous and diverse, commonly up to 10 to $20 \%$ of the assemblage, which is also considered another important characteristic of this province. This feature seems consistent with the Venezuelan material. Comparisons of Middle Cretaceous spores and pollen from West Africa as described by JARDINE \& MAGLOIRE (1965) with the same age assemblages from northeastern Peru have been summarized by BRENNER (1968). During the Late Albian and Early Cenomanian both areas contained identical species of Galeacornea and Elaterocolpites and also perinate trilete types. These features were used to correlate the Upper Albian to Lower Cenomanian in both areas. In Venezuela, the presently recorded assemblage does not include these genera, and they are absent with the exception of a single specimen of Perotriletes pannuceus. The foregoing suggests that the material studied should be considered older than Late Albian. 


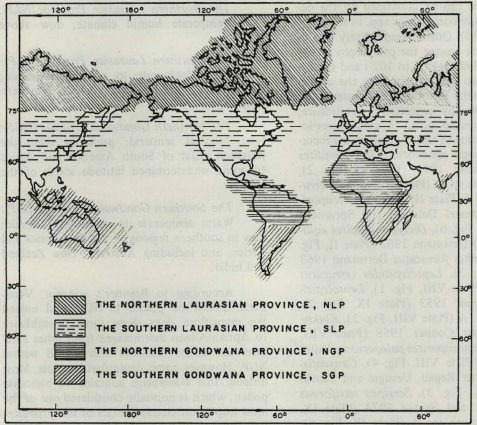

The concept of an African - South American Middle Cretaceous microfloral Province (A.S.A.), was introduced by HERNGREEN (1975) and extended in a contribution to the IV International Palynology Conferece, Lucknow, India (HERNGREEN, 1976). Later in 1981 , after reviewing the great majority of palynological literature concerning the Cretaceous period, HERNGREEN \& CHLONOVA (1981) established the following microfloral provinces:

1) The Boreal Early Cretaceous province of the Northern Hemisphere. vince.

2) The Late Cretaceous Normapolles ProProvince.

3) The Late Cretaceous Aquilapollenites

4) The pre-Albian West African-South American Province (WASA).

5) The Middle Cretaceous (Albian-Cenomanian) African-South American Province (ASA).

6) The Late Cretaceous Palmae Province of Africa and Northern South America.

7) The Gondwana Province.

8) The Senonian Nothofagidites Province.
The ASA phytogeographical belt is characterized by the presence of species bearing elaters and a rich morphological diversity of the ephedroid complex, high percentages and conspicuous diversification of the angiosperm pollen, the absence of bi- and trisaccate gymnosperms and the absence or scarcity of fern taxa. The Cenomanian (and Turonian to probably Coniacian) microfloras in the Sergipe (Brazil) and Congo Basins are dominated by Hexaporotricolpites. Based on these characte. ristics, HERNGREEN (1975) draws the southern boundary of the ASA floral province from Peru (and northern Chile?) to the Alagoas/ Sergipe basins into West Africa somewhere between the Congo and Angola to East Africa (Somalia). The northern boundary is drawn through the northernmost parts of South America and via Algeria and Tunisia to Israel. It is important and relevant to the present study that he considers the southern limit of the ASA microfloral province of a provisional nature.

Similarities include the presence of a great number and variety of the ephedroid complex and absence of bi- and trisaccate pollen. Dissimilarities include the absence of 
elater-bearing species. The lack of the high percentages and diversification of the angiosperm pollen in the recorded assemblage and the absence of Hexaporotricolpites genera are noteworthy. Taking these characteristics into account, the age of the presently recorded assemblage does not seem to be older than Albian. The palynomorph content of several borehole sections in the Barreirinhas and Sergipe basins of Brazil has been described and palynological zones have been established by HERNGREEN $(1973,1974,1975)$. Later in 1975 he compiled and summarized his results with some additional information from several other boreholes. The palynological zones of the Barreirinhas basin are as follow:

I. The Reyrea polymorphus zone; Early. -Middle Albian

IA. The Elateropollenites jardinet and Ephedripites irregularis subzone

IB. The Elaterosporites protensus and Elaterosporites verrucatus subzone

II. The Elaterocolpites-Elateroplicites-Sofrepites zone; Late Albian-Early-Cenomanian

IIA. The Classopollis spinosus subzone

IIB. The Classopollis braziliensis subzone

III. The Triorites africaensis zone; Late Cenomanian

IIIA. This zone is not formalized

IIIB. The Ephedripites elsikii subzone

Striking similarities exist between the recorded assemblage and Herngreen's $R$. polymorphus zone, more specifically with the I A subzone, except for the absence of $R$. polymorphus and $E$, jardinei. In fact HERNGREEN (1975) also mentions the infrequent occurrence of these species. Elater-bearing species were also not recorded from the Bahia or Sergipe/ Alagoas basins (MULLER, 1966). The recorded assemblage does not show any similarities with the other younger zones of HERNGREEN (1975). Based on the above-mentioned evidence, the age of the recorded Venezuelan assemblage is Early Middle Albian.

In terms of paleoenvironmental condi. tions, petrographical studies suggest that these beds are the product of a fluvial environment, probably a point bar, which may account for the kaolinite-rich and medium-to coarse-grained cross-stratified sandstone which encroaches on the flood-plain or the swamp during a short period and is recorded in the dark- to light-grey, bioturbated and fine sandy kaolinite-illite mixed claystone rich in plant remains. The source of the quartz sand and the detrital kaolinite-illite could be from the adjacent igneous/metamorphic high areas of the Guyana Shield.

In terms of palynological interpretations. the absence of marine palynomorphs, as well as the presence of Classopollis species in relatively high values, suggests a shallow water "sub. aerial" nonmarine environment. The high percentagem of numerous Ephedripites species and the diversity of the pteridophyte spores further suggest arid conditions. The total absence of bisaccate pollen indicates rather flat topography.

\section{BIBLIOGRAPHY}

BOER, N. P., HAMMEN, Th. V. \& WYMSTRA, T. A. A. - 1965 - Palynological study on the age of some borehole samples from the Amazonas Delta area, NW Brazil. Geol. Mijnb., 44 (66) : 243-258.

BRENNER, G. J. - 1968 - Middle Cretaceous spores and pollen from northeastern Peru. Pollen ct Spores, 10 (2) : $341-383$

BRENNER, G J. - 1976 - Middle Cretaceous flonal provinces and early migration of angiosperms. Origin and early evolution of angiosperms. Columbia University Press, New York.

HERNGREEN, G. F. W. - 1972 - Some new pollen grains from the Upper Cenomanian of Brazil. Pollen et Spores. $14(1): 97-112$.

HERNGREEN, G. F. W. - 1973 - Palynology of Albian-Cenomanian strata of borehole I-QS-I-MA, State of Mara. nhê, Brazil. Pollen et Spores, $15(3-4): 515-555$.

HERNGREEN, G. F. W. - 1974 - Middle Cretaceous palynomorphs from North-Eastern Brazil. Result of a palynological study of some boreholes and comparison with Africa and the Middle East. Sci. Géol. Bull., 27 $(1-2): 101-116$.

HERNGREEN, G. F. W. - 1975 - An Upper Senonian pollen assemblage of borehole 3.Pia-10-AL, State of Ala. goas, Brazill, Pollen et Spores, $17(1): 93-140$.

HERNGREEN, G. F. W - 1976 - Microfloral relationships between Africa and South America during the Middle and Upper Cretaceous. Abstr. 4th International Palynology Conference, p. 66-67. 
HERNGREEN, G. F. W. \& CHLONOVA, A. F. - 1981 - Cretaceous microfloral provinces. Pollen et Spores, 23 $(3-4): 441-557$.

JARDINE, S. \& MAGLOIRE, L. - 1965 - Palynologie et stratigraphie du Crefacedes bassins du Senegal et de Cote d Tvoire. Men. Bur. Rech. Géol. Miniérs., 32:187-245.

JEFFORDS, R. M. \& JONES, D. S. - 1959 - Preparation of slides for spores and other microfossils. Jour. Paleont $33: 344-347$.

LIMA, E. C. - 1974 - Bioestratigrafia da Bacta de Barreirinhas, An, XXVI Congr. Bras. Geol, p. 82-91.

MULLER, H. - 1966 - Palynological investigations on Cretaceous sediments in Northeastern Brazil. 2nd West African Micropaleontological Colloquium, p. 123-134.

REGALI, M. S. P., UESUGUI, N. \& SANTOS, A. S. - 1974 - Palinologia dos sedimentos meso-cenozóicos do Brasil. Bol. Tec. Petrobrás, 17(3): 177-191.

SINANOGLU, E. \& ERKMEN, U. - 1980 - Aptian-Albian palynostratigraphy of southeast Turkey and its place in the Lower Cretaceous floral provinces. Fifth Petroleum Congress of Turkey, p. 51-69.

\section{PLATES I-XVII}

Editors' note: The original plates have been reproduced here four to a page as an economy measure. All figures are at the same magnification, except in PI. XVII; according to the author, the bar scale in the figure in the upper left corner of each page represents $25 \mu \mathrm{m}$ and serves the entire page.

\section{PLATE I}

Figs. 1, 2-Cyathidites minor Couper 1953. Fig. 3-Cyathidites australis Couper 1953. Fig. 4 - Concavisporites sp. A.

\section{PLATE II}

Fig. 1 -Cyathidites sp. A. Fig. 2 - Gleicheniidites apilobatus Brenner 1963. Fig. 3-Verrucosisporites sp. A. Fig. 4 - Verrucosisporites sp. B. Fig. 5 - Concavisporites sp. B. Fig. 6 - Biretisporites cf, B. potoniaei Delcourt \& Sprumont 1955. Fig. 7 - Dictyophyllidites equiexinus (Couper) Dettmann 1963.

\section{PLATE III}

Fig. 1 -Cicatricosisporites patomacensis Brenner 1963. Fig. 2 - Cicatricosisporites avnimelechi Horowitz 1970. Fig. 3 -Cicatricosisporites dorogenesis Potonid 1934.

\section{PLATE IV} 1970 .

Fig. 1 -Cicatricosisporites patomacensis Brenner 1963. Fig. 2 -Cicatricosisporites avnimelechi Horowitz

\section{PLATE V}

Figs. 1, 2 - Cicatricosisporites australiensis (Cookson) Potonie 1965.

\section{PLATE VI}

Figs. 1, 2 -Cicatricosisporites recticicatricosus Dorning 1965. Fig, 3 -Cicatricosisporibes subrotundus Brenner 1963. Fig. 4 -Cicatricosisporites sp. A.

\section{PLATE VII}

Fig. 1 -Cicatricosisporites sp. B. Fig. 2 -Cicatricosisporites sp. C. Fig. 3 -Contignisporites fornicatus Dettmann 1963.

\section{PLATE VIII}

Fig. 1 - Leptolepitides verrucatus Couper 1958. Fig. 2 -Foveotriletes sp. A. Fig. 3 -Klukisporites variggatus Couper 1958. fig. 4 - Lycopodiumsporites pa/eoocenicus Dutta \& Sah 1970. 


\section{PLATE IX}

Fig. 1 - Hamulatisporis hamulatis Krutzsch 1959. Fig. 2 - Leptolepidites major Couper 1953. Fig. 3-Cin. gulatisporites verrucatus Regali, Uesugui \& Santos 1974. Fig. 4 -Cingulatisporites sp. A. Fig. 5 -Sergipea navifor. mis Regali, Uesugui \& Santos 1974. Fig. 6 - Coptospora sp. A. - Fig. 7 - Coptospora sp. B.

\section{PLATE $X$}

Fig. 1 - Velosporites sp. A. - Fig. 2 - Callialasporites dampieri (Baime) Dev 1961. Fig. 3 -Perotriletes pannucous Brenner 1973.

\section{PLATE XI}

Fig. 1 - Schizea reticulata Cookson 1956. Figs. 2, 3-Schizea certa Bolkhovitina 1956.

\section{PLATE XII}

Fig. 1 -Gnetaceaepollenites sp. A. Figs, 2,4-Gnetacesepollenites sp. B. Fig. 3 -Gnetacesepollenites sp. C Fig 5 - Gnetaceaepollenites sp. D. Fig. 6 - Gnetaceaepollenites sp. E.

\section{PLATE XIII}

Fig. 1, 2 -Ephedripites strigatus Brenner 1968. Fig. 3-Ephedripites sp. B. Fig. 4-Ephedripites ambonordes Brenner 1968

\section{PLATE XIV}

Fig. 1 - Ephedripites procerus Brenner 1968. Fig. 2 - Ephedripites barghoornil Pocok 1964. Figs. 3, 4 Ephedripites sp. C

\section{PLATE XV}

Fig. 1 - Ephedripites validus Brenner 1968. Fig. 2 - Ephedripites sp. D. Fig. 3 - Ephedripites sp. E. Fig. 4 Zonalapollenites sp. A. Fig. 5 - Retitricolpites vulgaris Pierce 1961 Fig. 6 - Eucommidites sp. A

\section{PLATE XVI}

Figs. 1,3,5 - Classopollis jardinei Herngreen 1973. Fig. 2 -Classopollis sp. A. Figs 4,6 - Classopollis obidosensis Groot \& Groot 1962.

\section{PLATE XVII}

Figs. 1,3-Classopollis sp. B. Fig. 2 -Classopollis torosus (Reissinger) Couper 1958. Fig. 4 - Retimonoco/. pites sp. A. Fig. 5 - Monosulcites sp. A. Fig. 6 - Spore type A. Fig. 7 - Spore type B. 

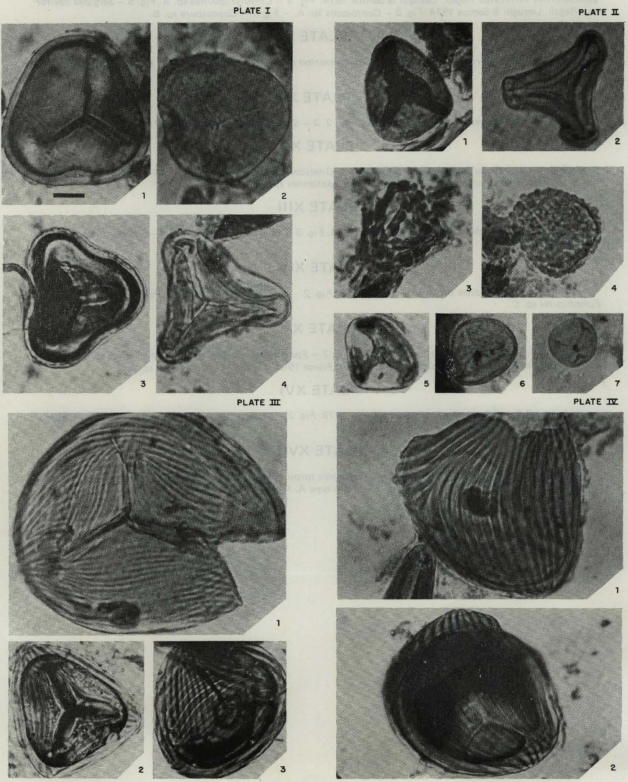


\section{PLATES V.VIII}
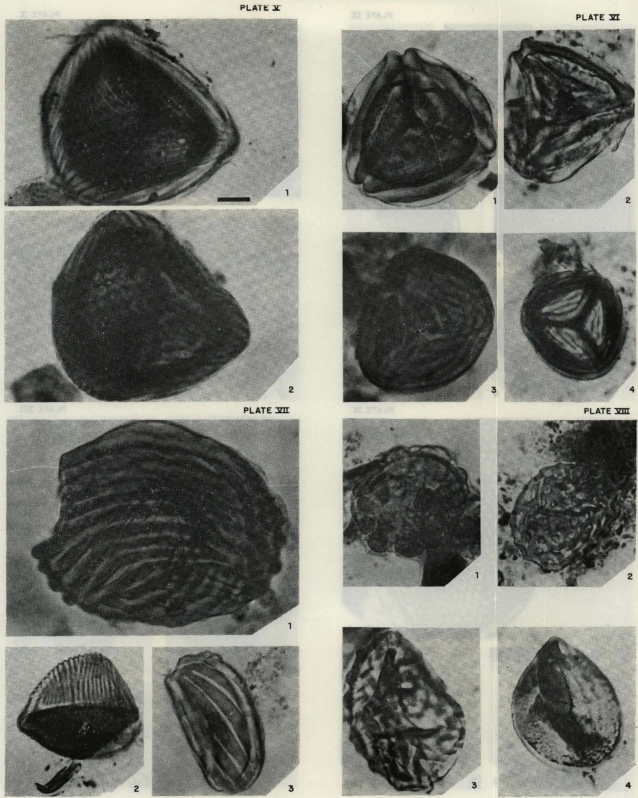
PLATES IX - $\mathbf{X}||$
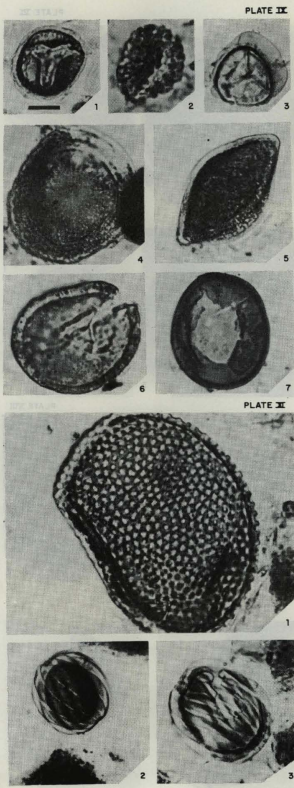

2

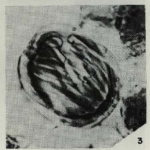

PLATE II
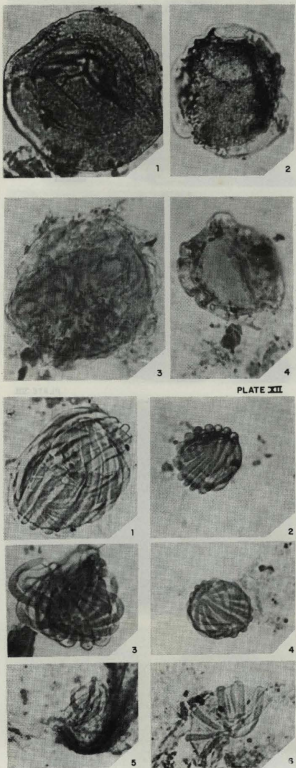
PLATES XIII - XVI
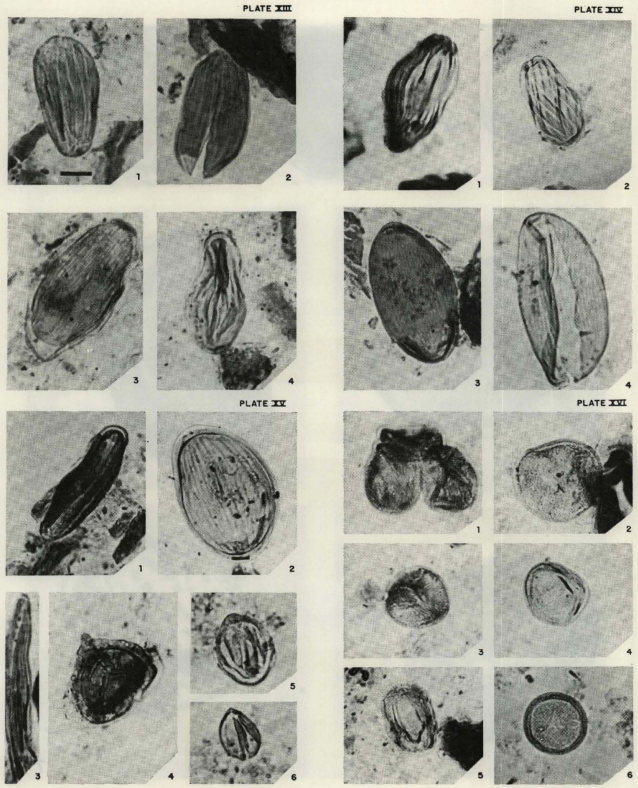

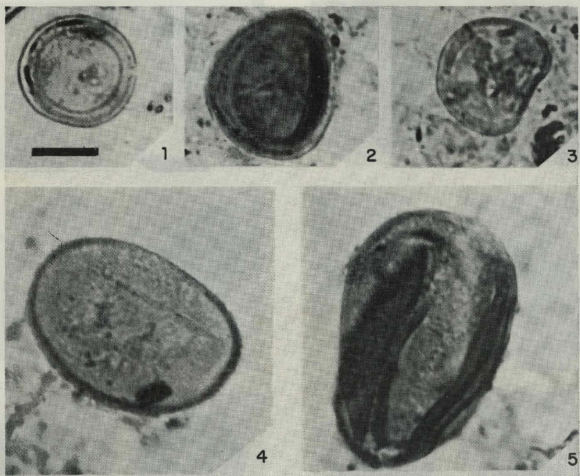

4
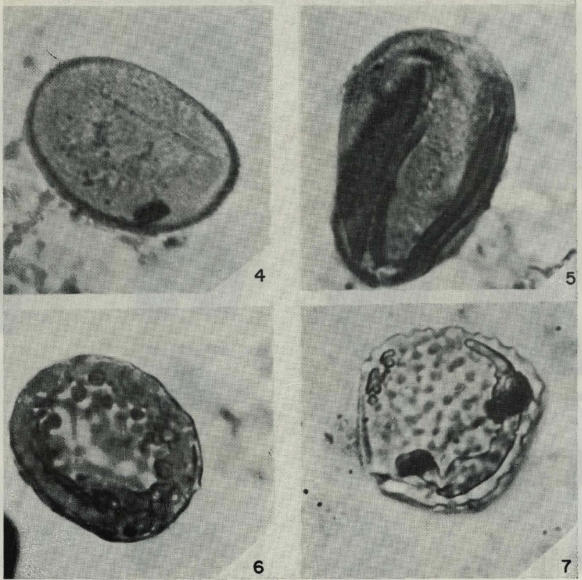